\title{
Indirect Organogenesis and Plant Regeneration in Pointed Gourd (Trichosanthes dioica Roxb.), an Important Perennial Vegetable
}

\author{
Manoranjan Prusty ${ }^{1 *}$, Kailash Chandra Samal ${ }^{2}$, Gouri Shankar Sahu ${ }^{2}$, \\ Tusar Ranjan Sahoo ${ }^{3}$, Laxmipriya Sahoo ${ }^{1}$ and Tania Seth ${ }^{1}$
}

${ }^{1}$ ICAR-Central Institute for Women in Agriculture, Bhubaneswar - 751003, Odisha, India

${ }^{2}$ Odisha University of Agriculture \& Technology, Bhubaneswar - 751003, Odisha, India

${ }^{3}$ KVK, ICAR-National Rice Research Institute, Cuttack - 753006, Odisha, India

*Corresponding author

\section{A B S T R A C T}

\begin{tabular}{l}
\hline Ke y w o r d s \\
$\begin{array}{l}\text { Pointed Gourd } \\
\text { (Trichosanthes } \\
\text { dioica), Indirect } \\
\text { Organogenesis, } \\
\text { Plant Regeneration }\end{array}$ \\
\hline Article Info \\
$\begin{array}{l}\text { Accepted: } \\
\text { 22 June 2020 } \\
\text { Available Online: } \\
\text { 10 July } 2020\end{array}$ \\
\hline
\end{tabular}

Pointed gourd (Trichosanthes dioica Roxb.) is one of the important nutritive cucurbit perennial vegetables in India and other tropical countries. In the present investigation, an efficient and reproducible protocol for clonal multiplication through in vitro culture of Pointed gourd (Trichosanthes dioica Roxb.) is standardized. High frequency organogenic callusing from shoot-tip and nodal segments was induced by culturing the explants on MS medium supplemented with $4 \mu \mathrm{M} 2-4-\mathrm{D}$. The maximum regeneration of shoots from callus $(72.47 \%)$ and highest callus weight per explant $(0.5 \mathrm{~g})$ was recorded in variety 'Nayagarh Local (Female)'. The highest number of shoots (3.0) per callus was regenerated from variety 'Swarna Aloukik (Female)' when cultured in MS medium fortified with BAP (4 $\mu \mathrm{M}$ ). The rooted plantlets were transferred to soil mixture (soil: sand: cocopit; $1: 1: 1$ ) and kept in greenhouse with $85 \%$ humidity. After 2-3 weeks hardening, the plantlets were successfully transplanted in the polybag or in the field with higher survival rate $(85 \%)$. No detectable variation in the regenerated plants with respect to morphology or growth characteristics was detected in the field as compared to the mother plant.These results may be great helpful for production of number of quality, uniform, disease free and desired plantlets for distribution to the farmers.

\section{Introduction}

Pointed gourd (Trichosanthes dioica Roxb., $2 n=22$ ) is one of the most important cucurbitaceous vegetables in tropical and subtropical regions of the world, particularly in India and Bangladesh. Pointed gourd is morphologically distinct from other cucurbitaceous species due to its wellestablished dioecism, perennial nature, and vegetative means of propagation. Fruits of pointed gourd are rich in proteins and vitamin $\mathrm{A}$ and also possess medicinal properties that can lower blood sugar and serum triglycerides. Seed propagation of pointed gourd is undesirable due to poor germination and unpredictable variation; thus, pointed gourd is multiplied through stem and root cuttings. Sexual progeny of pointed gourd, obtained through embryo culture, segregate 
for stem and leaf characters, revealing the highly heterozygous nature of pointed gourd clones. Hybridization followed by selection among segregating progeny and clonal selection are promising approaches for genetic improvement of this species. Pointed gourd is a nutritious perennial cucurbitaceous vegetable and is available in the vegetable markets of India and Bangladesh throughout the all seasons except severe cold two to three months from November to February.

Propagation through seed is undesirable due to poor germination and late flowering of sexual progeny (Seshadri and Parthasarathy, 2002). Seed-based population produce more than $50 \%$ of non fruiting staminate plants, where only $10 \%$ staminate plants are required for good pollination and fruit set. Scarification using $\mathrm{HCl}$ or $\mathrm{H}_{2} \mathrm{SO}_{4}$ also does not increase germination, and only $9.8 \%$ germination was obtained by culturing immature embryos (Kumar, 2008). Traditionally, $T$. dioicais multiplied through stem or root cuttings. Ideally, the cuttings are taken from mature plants to ensure stable sex expression, fruit type, yield, and quality. Stem cuttings are planted directly or pre -rooted. Although there is substantial intraspecific variation in pointed gourd vegetative traits, especially fruit characters, it is difficult to distinguish genotypes based on their external morphology alone (Hossain and Razzaque, 1999). In India, four high-yielding clones ('Rajendra Parwal-1', 'Rajendra Parwal-2', 'Swarna Rekha', and 'Swarna Alaukik') have been developed through hybridization and/or selection have been released in India by the Central Variety Release Committee (CVRC) for cultivation in different agro-ecological zones (Singh et al., 2009).

Tissue culture and micro-propagation can play a promising role in vegetative propagation of the plant. Plantlet regeneration in $T$. dioica has been achieved from shoot- tips, nodal explants, and immature and mature cotyledons (Hoque et al., 1998) and MS media (Murashige and Skoog, 1962) was widely used for micropropagation. Explants from field-grown plants show a high frequency of fungal contamination $(46.6 \%-$ $100 \%$, depending on season of explant collection), which can be minimized by a suitable antibiotic and fungicide treatment (Kumar, 2008). In the case of micropropagation using shoot-tip and nodal segments, about 8 shoots can be obtained from a single ex-plant in 4 weeks as compared to only 8-10 cuttings produced from each plant in one year by the conventional method of vegetative propagation. Therefore, micro-propagation has the potential for producing large numbers of quality propagules of elite clones in a short period. In India, the Agro Division of Cadila Pharmaceuticals Limited is producing (0.3 million plants perannum) of 'Anawal' pointed gourd through tissue culture at a price of Rs.12 each in the state of Gujarat. The sexassociated random amplified polymorphic DNA (RAPD) markers are utilized as a quality control to check the sex and uniformity of the propagules.

\section{Materials and Methods}

The experiment was carried out at the Department of Agricultural Biotechnology, College of Agriculture, Odisha University of Agriculture and Technology, Bhubaneswar, Odisha. Three pointed gourd cultivars were used for explant source and in-vitro plant regeneration. Two cultivars of Pointed gourd viz., 'Swarna Aloukik (Female)' and 'Swarna Aloukik (Male)' were collected from Regional Station of ICAR-Research Complex for Eastern Region, Ranchi and another one, 'Nayagarh Local (female)', a locally grown high yielding variety was collected from the farmer's field of Nayagarh district, Odisha. Both three cultivars were planted inside the 
Dept. of Agricultural Biotechnology, OUAT, Bhubaneswar for this experimentation. Shoot tip and nodal explants $(1-1.5 \mathrm{~cm})$ of above cultivars were used for in vitro culture at the laboratory of Department of Agricultural Biotechnology, College of Agriculture, OUAT, Bhubaneswar. For in vitro culture experiments Murashige and Skoog (1962) basal salts were used. The different plant growth regulators at different concentrations in different experiments used were Auxins viz., 2-4-Dichlorophenoxyacetic acid (2-4-D), Indole Butyric Acid (IBA), Indole-3- Acetic Acid (IAA) and Cytokinins viz., Benzylamino purine (BAP)

\section{Explant sterilization}

Young shoot tips and nodal portions of three pointed gourd cultivars were used as explants for in vitro culture. Explants were washed thoroughly under running tap water for 10 minutes and then treated with $0.5 \%(\mathrm{~m} / \mathrm{v})$ Carbendazim (Bavistin) and $0.1 \%$ Streptomycin $(\mathrm{m} / \mathrm{v})$ for $30 \mathrm{~min}$, followed by rinsing three to five times in sterile distilled water. Another round of disinfestation was done with 70\% alcohol for 30-60 seconds. Final round of disinfection was done by immersing the explant in $0.1 \%(\mathrm{~m} / \mathrm{v})$ aqueous mercuric chloride $\left(\mathrm{HgCl}_{2}\right)$ solution for 10 minutes and rinsed thrice with sterile double distilled water. The surface sterilized explants were trimmed at cut ends with surgical blade of size $1.0-1.5 \mathrm{~cm}$ inside the laminar airflow cabinet and were inoculated on culture media.

\section{Culture medium and conditions for in vitro culture}

MS basal salts supplemented with different concentrations of different growth regulators were used depending on the purpose of the individual experiment. Separate stock solutions of macronutrients, micronutrients, iron source and organic supplements were prepared. The medium was prepared by adding appropriate quantities of the stock solutions and The final volume was made up with distilled water. Sucrose (30 g/l) was added freshly to the medium. The $\mathrm{pH}$ of the medium was adjusted to 5.6 to 5.8 using $0.1 \mathrm{~N}$ HCL or $0.1 \mathrm{~N} \mathrm{NaOH}$. Agar (6 g/l) was added and dissolved by warming the medium. Appropriate quantities of medium were poured in test tubes $(150 \times 25 \mathrm{~mm}$ diameter) or bottles (300 ml capacity) before it solidify. The test tubes were then plugged with nonabsorbent cotton plugs and glass bottles were tightly closed with suitable caps. The medium was autoclaved at $121^{\circ} \mathrm{C}$ for 15 minutes and kept for solidification.

All the in vitro culture works were carried out aseptically in a laminar airflow chamber and the plant tissue culture experiments were conducted under defined conditions. For callusing, the inoculated tubes or bottles were incubated in the dark under $22 \pm 2{ }^{\circ} \mathrm{C}$. For regeneration of shoots and its multiplication, the temperature of the culture room was maintained at $25 \pm 2^{\circ} \mathrm{C}$ and uniform light (1000 lux) was provided by fluorescent tubes over a photoperiod of 16/8 hours light / dark cycle. The sub-culturing was done at 30 days interval. The number of explants forming callii was scored to calculate callus formation frequency after 45 days of culture. Regenerated shoots were then transferred to MS medium with IAA and IBA for shoot multiplication and subsequent induction of best roots.

Callus induction frequency $=$ (No. of explants forming callus/Total no. of explants) $x 100$

\section{Rooting and Acclimatization}

The rooting and shooting was observed in same medium. The healthy in vitro regenerated plantlets which having good 
numbers of root were selected for hardening. The plantlets were removed from the media and were washed with double distilled water properly to get rid of the traces of agar sticking to the roots. Then plantlets were transplanted in plastic pots containing autoclaved mixture of soil, sand and vermicompost (1:1:1) and kept in the green house. Watering of plants was done at regular intervals. The acclimatized plant showed normal growth and then transferred to big pots or soil after a period of one month. All the plants grown are morphologically identical. Regeneration frequency is calculated as follows.

Regeneration frequency $=$ (No. of regenerated from calli/Total no. of callus inoculated) $x 100$

All experiments were repeated thrice. Data were analysed by analysis of variance (ANOVA) to detect significant differences between means and C.D was carried out at $(\mathrm{p}=0.01)$. C.V was carried out where the means were significant.

\section{Results and Discussion}

Generally, a higher auxin concentration in growth medium induces callus formation. The quality and quantity of callus mass depends on various factors like explants, plant growth regulators and light/dark incubation etc. The plant growth regulator response on callus induction and shoot regeneration has been presented in Table-1, 2 \& 3. Greenish calli were emerged from the cut surface within 3-4 weeks from MS medium supplemented with different concentrations of $2,4-\mathrm{D}(0 \mu \mathrm{M}-$ $6 \mu \mathrm{M})$ in three different varieties of Trichosanthes dioica (Table 1, 2 and 3). The maximum response to callus induction percentage was observed on MS medium supplemented with $4 \mu \mathrm{M}$ of $2-4-\mathrm{D}$ in all the three varieties of pointed gourd. The highest callus induction percentage (72.47) was recorded in 'Nayagarh Local (Female)' (Fig. 1).There was no response of callus induction percentage with zero level of 2-4-D and there was very low response to callus induction percentage on MS medium supplemented with $1 \mu \mathrm{M}, 2-4-\mathrm{D}$ in all three cultivars. After 30 days of culture, the maximum weight of callus per explant was observed on MS medium supplemented with $4 \mu \mathrm{M} 2-4-\mathrm{D}$ in all the three varieties of pointed gourd. The highest callus weight was observed in variety 'Nayagarh Local (Female)' $(0.5 \mathrm{~g})$ followed by 'Swarna Aloukik (Female)' (0.48g) and Swarna Aloukik (Male) (0.46g). The lowest level of callus weight was observed on MS medium supplemented with $1 \mu \mathrm{M}$ of $2,4-\mathrm{D}$ in 'Swarna Aloukik (Female)' (0.12 g). Malek et al., (2010) obtained the best result for callus induction with different concentration of 2, 4$\mathrm{D}(0.1,0.5,1.0,1.5$, and $2.0 \mathrm{mg} / \mathrm{l})$. Thomas $e t$ al., (2004) worked on callus induction in ash gourd and they obtained maximum callus induction in MS medium supplemented with $4 \mu \mathrm{M}$ of 2, $4 \mathrm{D}$ which was in congruent to our findings. Saurabh et al., (2017) found that the MS medium supplemented with $0.5 \mathrm{mg} / \mathrm{L} \mathrm{BA}$ and $0.5 \mathrm{mg} / \mathrm{L} \mathrm{2,4-D}$ was most efficient for callus induction, followed by $0.5 \mathrm{mg} / \mathrm{L} \mathrm{Kn}$ and $0.5 \mathrm{mg} / \mathrm{L} 2,4-\mathrm{D}$.

Healthy and 3-4 weeks old well grown calli were transferred to MS basal media supplemented with BAP of different concentrations. Effect of plant growth regulator BAP on regeneration of shoot from callus of pointed gourd (Trichosanthes dioica) was presented in Table 4, 5 \& 6. MS basal medium fortified with $4 \mu \mathrm{M}$ BAP showed the maximum response to regeneration via calli inducing an average of 3 shoots per culture within 4-5 weeks in all the genotypes of pointed gourd (Trichosanthes dioica) (Fig. 2). The highest number of shoots (3.0) per callus was regenerated from variety 'Swarna Aloukik (Female)'followed by 2.67 shoots 
per callus in variety 'Swarna Aloukik (Male)' when MS fortified with BAP $(4 \mu \mathrm{M})$ whereas 2.33 shoots per callus, the lowest one was regenerated in variety 'Nayagarh Local (Female)'with same concentration of BAP. There was no shoot generation when MS fortified with zero level and $1.0 \mu \mathrm{M}$ BAP in all three cultivars. Thus it can be inferred from that the concentration of phytohormones in the media played a vital role in regeneration of plantlets. Plantlets were fully grown within 3-4 weeks with spontaneously good rooting. Vasudevan et al., (2001) reported similar results in pointed gourd cultured in MS medium supplemented with $1.50 \mathrm{mg} / \mathrm{l}$ of BAP. Kumar et al., (2016) also obtained significant shoot regeneration in in vitro multiplication of pointed gourd. Karim and Ullah (2011) obtained highest frequency of shoot formation $(89.67 \%)$, the maximum number of shoots (5.33) and the longest shoots $(0.9 \mathrm{~cm})$ in MS medium containing $1.0 \mathrm{mg} / \mathrm{l}$ BA through calli proliferation method in Teasle Gourd.

Table.1 Effect of plant growth regulator 2-4-D on Callus induction of Pointed gourd cv. Swarna Aloukik (Female)

\begin{tabular}{|c|c|c|c|}
\hline Treatment No. & $\begin{array}{c}\text { Treatment } \\
\text { MS+2-4-D( } \mathbf{\mu M})\end{array}$ & $\begin{array}{c}\text { Weight of callus after } \\
\mathbf{3 0} \text { days(gm) }\end{array}$ & Callus induction percentage \\
\hline $\mathbf{T 1}$ & 0 & 0.00 & 0.00 \\
\hline $\mathbf{T 2}$ & 1 & 0.12 & 16.33 \\
\hline $\mathbf{T 3}$ & 2 & 0.28 & 31.00 \\
\hline $\mathbf{T} 4$ & 3 & 0.32 & 42.00 \\
\hline $\mathbf{T 5}$ & $\mathbf{4}$ & $\mathbf{0 . 4 8}$ & $\mathbf{7 1 . 8 1}$ \\
\hline $\mathbf{T 6}$ & 5 & 0.33 & 43.95 \\
\hline $\mathbf{T} 7$ & 6 & 0.14 & 20.33 \\
\hline $\mathbf{S E} \pm$ & & 0.02 & 1.19 \\
\hline $\mathbf{C D}(\mathbf{0 . 0 1})$ & & 0.07 & 4.86 \\
\hline
\end{tabular}

N.B- Medium used- Murashige and Skoog (MS) medium+ Sucrose (3.0\%)

Table.2 Effect of plant growth regulators 2-4-D on callus induction of Pointed gourd (Trichosanthes dioica) in cv. Swarna Aloukik (Male)

\begin{tabular}{|c|c|c|c|}
\hline Treatment No. & $\begin{array}{c}\text { Treatment } \\
\text { MS+2-4-D( } \mathbf{\mu M})\end{array}$ & $\begin{array}{c}\text { Weight of callus } \\
\text { after 30 days(gm) }\end{array}$ & $\begin{array}{c}\text { Callus induction } \\
\text { percentage }\end{array}$ \\
\hline T1 & 0 & 0.00 & 0.00 \\
\hline T2 & 1 & 0.14 & 16.00 \\
\hline T3 & 2 & 0.26 & 31.00 \\
\hline T4 & 3 & 0.30 & 41.50 \\
\hline T5 & $\mathbf{4}$ & $\mathbf{0 . 4 6}$ & $\mathbf{7 1 . 0 0}$ \\
\hline T6 & 5 & 0.31 & 43.33 \\
\hline T7 & 6 & 0.15 & 20.00 \\
\hline CD $(\mathbf{0 . 0 1})$ & & 0.07 & 4.86 \\
\hline
\end{tabular}

N.B- Medium used- Murashige and Skoog (MS) medium+ Sucrose (3.0\%) 
Table.3 Effect of plant growth regulators 2-4-D on callus induction of Pointed gourd (Trichosanthes dioica) cv. Nayagarh Local (Female)

\begin{tabular}{|c|c|c|c|}
\hline Treatment No. & Treatment $(\boldsymbol{\mu M})$ & $\begin{array}{c}\text { Weight of callus after } \\
\text { 30 days(gm) }\end{array}$ & $\begin{array}{c}\text { Callus induction } \\
\text { percentage }\end{array}$ \\
\hline T1 & 0 & 0.00 & 0.00 \\
\hline T2 & 1 & 0.15 & 15.33 \\
\hline T3 & 2 & 0.29 & 30.33 \\
\hline T4 & 3 & 0.31 & 41.00 \\
\hline T5 & $\mathbf{4}$ & $\mathbf{0 . 5 0}$ & $\mathbf{7 2 . 4 7}$ \\
\hline T6 & 5 & 0.31 & 43.33 \\
\hline T7 & 6 & 0.16 & 29.00 \\
\hline CD (0.01) & & 0.07 & 4.86 \\
\hline
\end{tabular}

N.B- Medium used- Murashige and Skoog (MS) medium+ Sucrose (3.0\%)

Table.4 Effect of plant growth regulator BAP on shoot regeneration of Pointed gourd (Trichosanthes dioica) in cv. Swarna Aloukik (Female)

\begin{tabular}{|c|c|c|}
\hline Treatment No. & Treatment $(\boldsymbol{\mu M})$ & $\begin{array}{c}\text { No. of shoots regenerated per } \\
\text { callus }\end{array}$ \\
\hline T1 & $0.0 \mathrm{BAP}$ & 0.0 \\
\hline T2 & 1.0 BAP & 0.0 \\
\hline T3 & $2.0 \mathrm{BAP}$ & 1.0 \\
\hline $\mathbf{T} 4$ & $3.0 \mathrm{BAP}$ & 1.3 \\
\hline $\mathbf{T 5}$ & $\mathbf{4 . 0} \mathrm{BAP}$ & $\mathbf{3 . 0}$ \\
\hline $\mathbf{T} 6$ & $5.0 \mathrm{BAP}$ & 1.3 \\
\hline $\mathbf{T} 7$ & 6.0 BAP & 0.3 \\
\hline CD $(\mathbf{0 . 0 1})$ & & 1.36 \\
\hline
\end{tabular}

N.B- Medium used- Murashige and Skoog (MS) medium+ Sucrose (3.0\%)

Table.5 Effect of plant growth regulator BAP on shoot regeneration of Pointed gourd (Trichosanthes dioica) in cv. Swarna Aloukik (Male)

\begin{tabular}{|c|c|c|}
\hline Treatment No. & Treatment $(\boldsymbol{\mu M})$ & $\begin{array}{c}\text { No. of shoots regenerated per } \\
\text { callus }\end{array}$ \\
\hline T1 & $0.0 \mathrm{BAP}$ & 0.0 \\
\hline T2 & $1.0 \mathrm{BAP}$ & 0.0 \\
\hline $\mathbf{T 3}$ & $2.0 \mathrm{BAP}$ & 1.0 \\
\hline $\mathbf{T} 4$ & $3.0 \mathrm{BAP}$ & 1.3 \\
\hline $\mathbf{T 5}$ & $\mathbf{4 . 0} \mathrm{BAP}$ & $\mathbf{2 . 6 7}$ \\
\hline T6 & $5.0 \mathrm{BAP}$ & 1.3 \\
\hline $\mathbf{T} 7$ & 6.0 BAP & 0.3 \\
\hline $\mathbf{C D}(\mathbf{0 . 0 1})$ & & 1.36 \\
\hline
\end{tabular}

N.B- Medium used- Murashige and Skoog (MS) medium+ Sucrose (3.0\%) 
Table.6 Effect of plant growth regulator BAP on shoot regeneration of pointed gourd (Trichosanthes dioica) cv. Nayagarh Local (Female)

\begin{tabular}{|c|c|c|}
\hline Treatment No. & $\begin{array}{c}\text { Treatment } \\
(\boldsymbol{\mu M})\end{array}$ & $\begin{array}{c}\text { No. of shoots regenarated per } \\
\text { callus }\end{array}$ \\
\hline T1 & $0.0 \mathrm{BAP}$ & 0.0 \\
\hline T2 & $1.0 \mathrm{BAP}$ & 0.0 \\
\hline T3 & $2.0 \mathrm{BAP}$ & 0.7 \\
\hline $\mathbf{T} 4$ & $3.0 \mathrm{BAP}$ & 1.3 \\
\hline $\mathbf{T 5}$ & $\mathbf{4 . 0} \mathrm{BAP}$ & $\mathbf{2 . 3 3}$ \\
\hline $\mathbf{T 6}$ & $5.0 \mathrm{BAP}$ & 1.0 \\
\hline $\mathbf{T} 7$ & $6.0 \mathrm{BAP}$ & 0.3 \\
\hline $\mathbf{C D}(\mathbf{0 . 0 1})$ & & 1.36 \\
\hline
\end{tabular}

N.B- Medium used- Murashige and Skoog (MS) medium+ Sucrose (3.0\%)

Figure.1 Indirect organogenesis of Pointed gourd (Trichosanthes dioica Roxb.) after 30 days

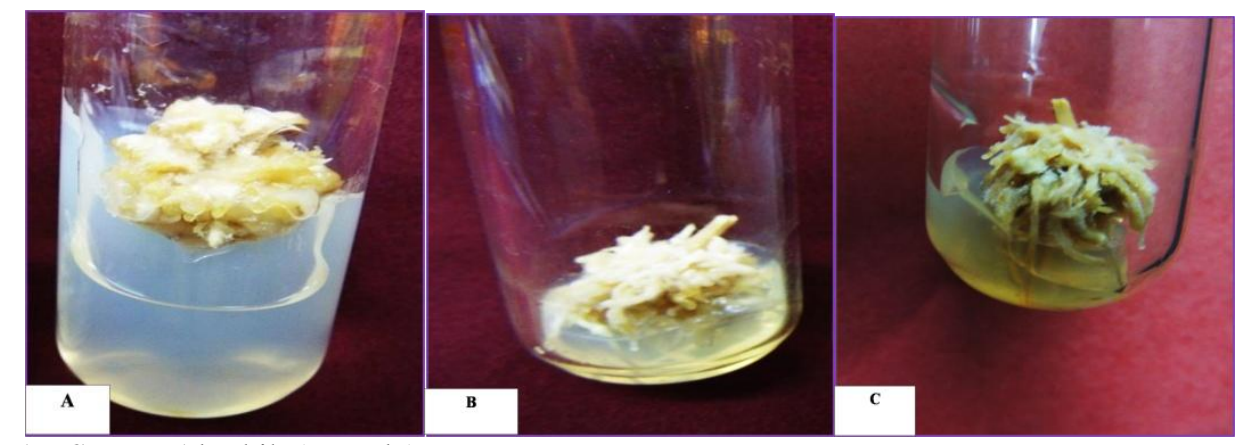
A. SwarnaAloukik (Female)
B. SwarnaAloukik (Male)
C. Nayagarh Local (Female)

Fig.2 Indirect regeneration from callus of Pointed gourd (Trichosanthes dioica Roxb.)

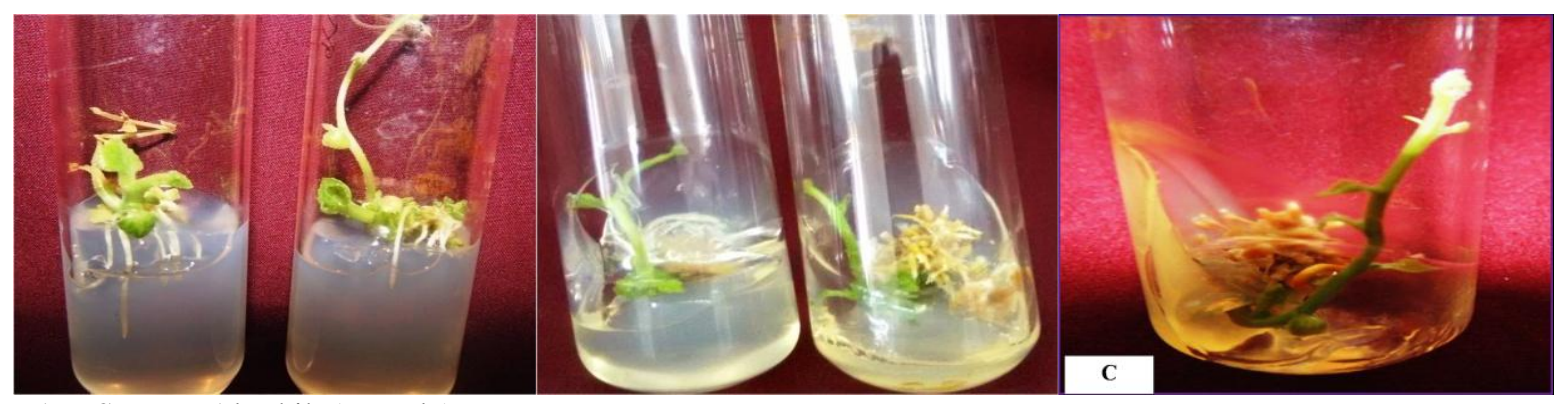
A. Swarna Aloukik (Female)
B. Swarna Aloukik (Male)
C. Nayagarh Local (Female)

In plant tissue culture, the ultimate success of in vitro regenerated plantlets lies in its growth in the external environmental field conditions.
The well elongated healthy plantlets with good roots were selected for hardening. These roots of healthy plantlets were washed gently 
with sterile distilled water to remove all traces of MS media. After one day these plants were pre-hardened to the plastic glass containing autoclaved mixture of soil: vermin-compost: cocopit (1:1:1) and kept into the green house. After 2 weeks the plantlets were transplanted from plastic glass to earthen pots. Higher survival rate $(85 \%)$ was observed. No detectable variation in the plants with respect to morphology or growth characteristics was detected in the field as compared to the mother plant.

In conclusion the best result was observed in MS medium containing $4 \mu \mathrm{M} 2-4-D$ for callus induction percentage, and weight of callus after 30 days, The best results of regeneration of shoots from calli was observed in MS medium supplemented with $4 \mu \mathrm{M}$ BAP. These results may be great helpful for the in vitro multiplication and indirect plant regeneration of pointed gourd.

\section{Acknowledgments}

The authors wish to acknowledge to the Department of Biotechnology, Govt. of India for providing fund under PG-HRD teaching program for student research.

\section{Compliance with Ethical Standards}

\section{Conflict of interest}

The authors declare that they have no conflict of interests.

\section{References}

Hoque, M.E., Bhomik, A. and Khalequzzaman, M. (1998). In vitro culture of pointed gourd. Thai. J. Agr. Sci. 31:369-374.

Hossain, S.M.M. and Razzaque, M.A. (1999). Collection, conservation and utilization of indigenous vegetables in Bangladesh. p. 21-42. In: L.M. Ingle and N.C. Altoveros (eds.), Collection, conservation and utilization of indigenous vegetables, A.V.R.D.C. Publ., Tainan, Taiwan.

Karim, M.A. and Ullah, M.A. (2011). In vitro regeneration of Teasle Gourd. 2nd International Conference on Biotechnology and Food Science. IPCBEE vol.7, IACSIT Press, Singapore.

Kumar, S. (2008). Micropropagation of pointed gourd and identification of RAPD markers associated with its reproductive traits. $P h$. D. Diss., Banaras Hindu Univ. Varanasi, India.

Kumar, S., Singh H., Pandey, V. and Singh, B.D. (2016). In vitro multiplication of pointed gourd through nodal explant culture, and testing genetic fidelity of micro propagated plants using RAPD markers. Indian Journal of Biotechnology. 15:581588.

Malek, A.M., Miah, B.A.M., Al-Amin, M., Khanam, D. and Khatun, M. (2007). In vitro regeneration in pointed gourd. Bangladesh J Agri Res. 32: 461-471.

Murashige, T. and Skoog, F. (1962). A revised medium for rapid growth and bioassays with tobacco tissue culture. Physiol. Plant. 15: 473-479.

Press India, New Delhi, India.

Saurabh, S., Prasad, D. \& Vidyarthi, A.S. (2017). In vitro propagation of Trichosanthus dioica Roxb. for nutritional security. $J$. Crop Sci. Biotechnol. 20, 81-87.

Seshadri, V.S., and Parthasarathy, V.A. (2002).Cucurbits. p. 493-629 In: T.K. Bose, J. Kabir T. K. Maity, V.A. Parthasarathy, and M.G. Som (eds.), Vegetable crops. NayaProkash, Kolkata, India.

Singh, H.P., Rai, M., Pandey, S. and Kumar, S. (2009). Vegetable varieties of India. Studium

Thomas, T.D. and Sreejesh, K.R. (2004). Callus induction and plant regeneration from cotyledon explants of ash gourd (Benincasahispida L.). Sci. Hort. 100: 359-367.

Vasudevan, A., Selvaraj, N., Kumar, Suresh, P. and Ganapathi, A. (2001). Multiple shoot Induction from the Shoot Tip Explants of Cucumber (Cucumissativus L.). Cucurbit Genetics Cooperative Report. 24: 8-12. 


\section{How to cite this article:}

Manoranjan Prusty, Kailash Chandra Samal, Gouri Shankar Sahu, Tusar Ranjan Sahoo Laxmipriya Sahoo and Tania Seth. 2020. Indirect Organogenesis and Plant Regeneration in Pointed Gourd (Trichosanthes dioica Roxb.), an Important Perennial Vegetable. Int.J.Curr.Microbiol.App.Sci. 9(07): 2776-2784. doi: https://doi.org/10.20546/ijcmas.2020.907.327 